\title{
Ovarian Activity at Naturally Attained Oestrus in the Sow. An Ultrasonographic and LH Study
}

\author{
By A.M. Dalin, T. Nanda*, F. Hultén and S. Einarsson
}

Department of Obstetrics and Gynaecology, Faculty of Veterinary Medicine, Swedish University of Agricultural Sciences, Uppsala, Sweden.

\begin{abstract}
Dalin, A.M., T. Nanda, F. Hultén and S. Einarsson: Ovarian activity at naturally attained oestrus in the sow. An ultrasonographic and LH study. Acta vet. scand. 1995, 36, 377-382. - In 6 multiparous crossbred sows (2nd to 4th parity, Swedish Landrace $x$ Swedish Yorkshire), 15 proosestrous-oestrous periods during 2 oestrous cycles were studied after weaning. The animals were controlled for oestrus, and the follicular growth and ovulation in their ovaries were followed by transrectal ultrasonography. Blood was sampled through indwelling catheters for analyses of $\mathrm{LH}$ and progesterone $\left(\mathrm{P}_{4}\right)$.

The duration of oestrus (standing reflex) was $47 \pm 12.4 \mathrm{~h}$, and the interval from onset of standing reflex until the end of ovulation was $39 \pm 12.4 \mathrm{~h}$ (range 20-64 h). The LH peak concentration was $3.7 \pm 0.8 \mu \mathrm{g} / \mathrm{l}$, and the interval from $\mathrm{LH}$ peak level until ovulation was $23 \pm 8.4 \mathrm{~h}$ (range 8-32 h). The onset of standing reflex occurred in average 13 $h$ before the LH peak level (range $-4-+36 \mathrm{~h}$ ).

The peripheral plasma concentration of $\mathrm{P}_{4}$ showed a normal cyclic pattern in all animals. Low levels (mean levels, $1.1-1.3 \mathrm{nmol} / \mathrm{l}$ ) were seen during prooestrus and oestrus, high mean levels were found on days 10-16 (45-75 nmol/l) in the oestrous cycle.

It was concluded that for an accurate determination of ovulation, each animal has to be examined repeatedly. Ultrasonography is a most valuable tool for this purpose.
\end{abstract}

ultrasonography; ovulation.

\section{Introduction}

Ultrasonographic examination has been used in pigs since the beginning of the 1980's. Initially, it was used for diagnosis of pregnancies in sows (e.g. Inaba et al. 1983, Botero et al. 1986) and later for determination of follicular maturation and ovulation, by the transcutaneous (Habeck 1989, Weitze et al. 1989, Weitze et al. 1990, Willmen et al. 1992) and transrectal methods (Soede et al. 1991, Soede et al. 1992, Soede \& Kemp 1993).

The hormonal patterns after weaning and

* Present address: Department of Gynaecology and Obstetrics, College of Veterinary Science, Haryana, India. during the following oestrus have been studied in sows (e.g. Ash \& Heap 1975, Kunavongkrit et al. 1983, Kirkwood et al. 1984) and in gilts during the oestrous cycle (e.g. Hendrichs et al. 1972, Karlbom et al. 1982). So far, only 1 study of the oestrous cycle in the sow has included an analysis of hormonal patterns and simultaneous ultrasonography of the ovaries (Soede et al. 1994).

The aim of the present study was to correlate naturally attained oestrous behaviour (standing reflex) with ovarian activity as recorded by ultrasonography and with plasma LH levels. Plasma progesterone levels were also determined as a control of the oestrous cycles. 


\section{Materials and methods}

Animals, housing and feeding

Six multiparous crossbred sows (2nd to 4th parity, Swedish Landrace $\mathrm{x}$ Swedish Yorkshire) aged from 1.5 to 2.5 years were used. The animals were brought from a commercial farm to the Dept. of Obstetrics and Gynaecology on the day of weaning. The preceding lactation periods varied from 32 to 43 days.

Throughout the experimental period, they were housed in individual pens in a stall with an adult boar and were fed a commercial ration twice daily according to Swedish breeding stock standards (Göransson 1984). The sows were followed during 2 oestrous cycles and 3 oestruses. They were slaughtered around the time of ovulation in the third oestrus. Altogether 15 prooestrus-oestrous periods were taken into account, 3 were excluded due to incomplete records.

\section{Oestrous detection and blood sampling}

The animals were examined twice daily for signs of prooestrus by inspection of the vulva for swelling and reddening. Once the signs of prooestrus appeared, the standing reflex was controlled 6 times daily (every $4 \mathrm{~h}$ ) in the presence of a boar. On the day after arrival, a permanent indwelling catheter was inserted into the sow's jugular vein under general anaesthesia (Rodriguez \& Kunavongkrit 1983). Blood was sampled once daily (at 8.00 am) except during prooestrus and oestrus, when samples were taken every $4 \mathrm{~h}$ until ovulation was completed. Blood was collected in heparinised tubes, centrifuged at $3000 \mathrm{rpm}$ for $10 \mathrm{~min}$, and the plasma was then stored at $-20^{\circ} \mathrm{C}$ until analysed.

\section{Hormone analyses}

The hormones were analysed at the Dept. of Clinical Chemistry. The samples collected every $4 \mathrm{~h}$ were analysed for LH by Radio Im- muno Assay (Stupniki \& Madej 1986). Progesterone, $\mathrm{P}_{4}$, was analysed in every second day samples by Enzyme Immuno Assay (Amerlite Kodak Clinical Diagnosis Ltd., England). The method has previously been validated for progesterone determination in the pig (Rojkittikhun et al. 1993). The sensitivity of the assay systems for $\mathrm{LH}$ and $\mathrm{P}_{4}$ were $0.3 \mu \mathrm{g}$ and $<1$ $\mathrm{nmol} / \mathrm{l}$, respectively.

The duration of the preovulatory $\mathrm{LH}$ peak was set as the LH level being higher than the basal level (mean $+1 \mathrm{sd}$ ). The basal LH level was the mean of at least 5 samples preceding the rise of the preovulatory peak.

\section{Ultrasonographic examination}

Transrectal ultrasonography was used to study follicular activity and ovulation time as described by Soede et al. (1992). An annular array sector scanner (Scanner 250, Pie Medical B.V., Maastricht, The Netherlands) with a multi-angle probe $(5 \mathrm{MHz})$ was used. For immobilisation during scanning, the sows were placed in a wagon especially designed for this purpose.

The probe, covered with a plastic sheath containing gel and on the outside with abundant lubricant, was carefully introduced into the rectum. The probe was rotated slightly towards both sides to examine the ovaries. The size of the follicles was measured as the diameter of the antrum of the follicle excluding the follicle wall. The time of ovulation was taken as the time when all, or almost all, follicles had ovulated. All sows were scanned every second day during metoestrus and dioestrus, and daily during prooestrus and oestrus. From $16 \mathrm{~h}$ after the start of the standing oestrus until completed ovulation, they were scanned every $4 \mathrm{~h}$.

Statistical analyses

Data were analysed using the Statistical Ana- 
lyses System (SAS Institute Inc. 1985). The CORR procedure was used to calculate correlations, while GLM was used to analyse linear models. Sow identity and the prooestrousoestrous period were included in the model. For statistical analyses of the ovulatory LH peak, the area above the basal level (mean +1 sd) was measured by a Digiplan electronic integrator (Kontron Messgeräte, $\mathrm{GmbH}$, Germany).

\section{Results}

The weaning to onset of oestrous interval was $5.2 \pm 1.1$ (mean \pm sd) days (range 4 to 7 days) The mean duration of the first and second oestrous cycles was $21.8 \pm 1.3$ days (range 19.5-24 days). For all proestruses (first to third), the mean duration was $50 \pm 20.0 \mathrm{~h}$ (range 16-76 h). The duration of the standing oestrus during the first and second oestruses was $47 \pm 9.2 \mathrm{~h}(10$ oestruses, range $36-68 \mathrm{~h})$, no significant difference was seen between animals or between the first and second oestruses. The interval from the onset of the standing oestrus until the end of ovulation was $39 \pm 12.4$ hours, with a wide range (20-64 h). However, the differences between animals and between periods were not significant. There was no significant correlation between the duration of the standing oestrus and the interval from onset of standing reflex until ovulation.

The transrectal ultrasonography did not have any negative effects on the sows, despite frequent examinations. The ovaries were most easily detected by ultrasonography during the follicular phase. Around the start of prooestrus, follicles with a diameter of 0.2$0.3 \mathrm{~cm}$ up to $0.6 \mathrm{~cm}$ were seen. Before ovulation, the largest mature follicles were approximately $0.9 \mathrm{~cm}$ in diameter. From day 3 and onwards, corpora lutea were visible in approximately half of the examined animals. At dioestrus, small mid-cycle follicles $(\leq 0.5 \mathrm{~cm})$ were seen.

The basal LH levels in individual sows were low and varied from $0.9 \pm 0.13 \mu \mathrm{g} / 1$ to $1.5 \pm$ $0.07 \mu \mathrm{g} / \mathrm{l}$. The $\mathrm{LH}$ peak concentration was 3.7 $\pm 0.8 \mu \mathrm{g} / \mathrm{l}$ (range 2.2-5.1 $\mu \mathrm{g} / \mathrm{l}$ ) and it differed significantly between animals $(\mathrm{p} \leq 0.05)$ but not between oestrous periods. The duration of the preovulatory LH peak was $36 \pm 8.1 \mathrm{~h}$ (range 24-49 hours), but the differences between animals and between oestrous periods were not significant. There was no significant correlation between the LH peak concentration and the interval from standing oestrus until ovulation or between LH peak concentration and oestrous duration. The mean interval between the LH peak concentration and ovulation was $23 \pm 8.4 \mathrm{~h}$, but with a wide variation (range 8-32 h), the differences between animals and between oestrous periods not being significant. There was no significant correlation between the interval from $\mathrm{LH}$ peak until ovulation and oestrous duration. On average, the onset of the standing reflex occurred $13 \pm 12.5 \mathrm{~h}$ before the $\mathrm{LH}$ peak level. The variation was wide, and in individual animals LH levels peaked $4 \mathrm{~h}$ before up to 36 hours after the beginning of the standing reflex, the difference being significant between animals $(p \leq 0.05)$ but not between oestrous periods. The correlation between the interval from $\mathrm{LH}$ peak level until ovulation and the interval from the onset of standing reflex until ovulation was significant $(\mathrm{r}=0.77, \mathrm{p} \leq 0.01)$. There was a significant, negative correlation between the duration of the preovulatory LH peak and the interval from the onset of the standing reflex until ovulation $(r=-0.79, p \leq$ 0.01 ). There was, however, no significant correlation between the preovulatory LH peakarea (concentration $\mathrm{x}$ duration) and interval from standing reflex to ovulation or between the LH peak-area and oestrous duration. 
All sows had low $\mathrm{P}_{4}$ concentrations from weaning to first oestrus, ranging from 0.8 to 1.8 $\mathrm{nmol} / \mathrm{l}$. Thereafter, peripheral plasma concentrations of $\mathrm{P}_{4}$ showed a cyclic pattern in all animals during the 2 oestrous cycles. The $P_{4}$ concentrations were $1.3 \pm 0.6 \mathrm{nmol} / \mathrm{l}$ and $1.1 \pm$ $0.5 \mathrm{nmol} / 1$ on the first day of prooestrus and oestrus, respectively. High $\mathrm{P}_{4}$ concentrations were found during days 10-16 (range 46 - 75 $\mathrm{nmol} / \mathrm{l})$.

\section{Discussion}

The present study was done in sows with naturally attained oestruses. The animals showed oestrus within 7 days of weaning which can be expected in multiparous sows (Einarsson \& Settergren 1974, Karlberg 1980). The average length of the prooestrus and oestrous periods and the oestrous cycles were within the physiological range. Cyclicity, as measured by progesterone levels, followed the pattern seen in normal cycling animals (Andersson \& Einarsson 1980, Karlbom et al. 1982).

The size of the follicles at the time of ovulation was in agreement with the study of $\mathrm{Ha}$ beck (1989). In the present study, the mean time from the start of standing oestrus until ovulation was $39 \mathrm{~h}$, with a wide range in individual animals. A similar mean duration from onset of oestrus to ovulation have been reported as $39 \mathrm{~h}$ by Habeck (1989) and as $39 \mathrm{~h}$ by Soede et al. (1994). Weitze et al. (1992) showed in a field trial that most sows $(82 \%)$ ovulated within 32 to $56 \mathrm{~h}$ after the beginning of the standing reflex, and that the animals ovulated within a wide range, approximately 24 to $80 \mathrm{~h}$. Soede et al. $(1992,1994)$ have also shown a wide variation between onset of oestrus and ovulation, 24-68 $\mathrm{h}$ and 16-52 h, respectively. Furthermore, Soede et al. (1994) found that the longer the duration of oestrus, the longer the interval from onset of oestrus to ovulation, showing that ovulation takes place at a constant relative moment of the total oestrous period (approximately 70\%). In the present study, no correlation was found between the duration of standing oestrous and the interval from the onset of standing reflex until ovulation. However, this may be due to the small number of observations and the fact that a large variation between animals was noted.

The LH concentrations reached during the preovulatory $\mathrm{LH}$ peaks and their duration in this study were in accordance with an earlier study of LH in gilts (Andersson et al. 1984). The peak LH level was seen approximately 13 $\mathrm{h}$ after the start of the standing reflex, though individual variations were large. Tilton et al. (1982) also observed that the LH peak level in relation to the onset of oestrus varied considerably in the sows. The same observations were made by Soede et al. (1994). The present study also showed that there was a wide variation in the interval from $\mathrm{LH}$ peak levels until ovulation in the sows, the mean interval being 23 h. Soede et al. (1994) demonstrated a somewhat longer mean duration $(30 \mathrm{~h})$ but a more narrow range ( 26-34 hours).

The value of ultrasonography as a diagnostic tool in gynaecological research was evident from the present study, which supports earlier reports (Weitze et al. 1989, Weitze et al. 1990, Soede et al. 1991, 1992, 1994). The transrectal method did not have any negative effects on the sows despite frequent examinations. This is in agreement with earlier studies (Soede et al. 1991).

\section{Conclusion}

In 15 naturally attained oestruses in 6 sows, the mean interval from the onset of the standing reflex to ovulation was $39 \mathrm{~h}$ and between the $\mathrm{LH}$ peak concentration and ovulation 23 h. However, considerable variations were seen among the animals. The time of ovulation can thus not be predicted from the onset 
of the standing reflex or from the LH peak. For an accurate determination of ovulation, each individual animal has to be examined repeatedly, and ultrasonography is a most valuable tool for this purpose.

\section{Acknowledgement}

This study was supported by The Swedish International Programme on Animal Reproduction (SIPAR)

\section{References}

Andersson $A-M$, Einarsson $S$ : Studies on the oestrus and ovarian activity during five successive oestrous cycles in gilts. Acta vet. scand., 1980, 21, 677 - 688.

Andersson A-M, Einarsson S, Edqvist LE: Endocrine pattern and external oestrous symptoms at second and fourth oestrus in gilts. Anim. Repr. Sci., 1984, 6, 301-310.

Ash RW, Heap RB: Oestrogen, progesterone and corticosteriod concentration in peripheral plasma of sows during pregnancy, parturation, lactation and after weaning. J. Endocrinol., 1975, 64, 141-154.

Botero O, Martinat-Botté F, Bariteau F: Use of ultrasound scanning in swine for detection of pregnancy and some pathological conditions. Theriogenology, 1986, 26, 267 - 278.

Einarsson S, Settergren I: Fruktsamhet och utslagsorsaker $\mathrm{i}$ ett antal mellansvenska suggbesättningar (Fertility and culling in some pig breeding herds in Sweden). Nord. Vet. Med. , 1974, $26,576-584$.

Göransson $L$ : Förslag till ny utfodringsnorm till suggor. (Suggested new feeding norm for sows). Swedish University of Agricultural Sciences, Research Information Centre. Fakta-Husdjur, 1984, no 3.

Habeck OJM: Die Anwendung eines Real-timeSektorscanners (5 MHz) zur Ovarkontrolle bei der Sau (The use of a real-time sector scanner $\left(5 \mathrm{MH}_{3}\right)$ for ovarian investigation in the sow). Thesis, Hannover, 1989.

Hendrichs DM, Guthrie HD, Handlin DL: Plasma oestrogen, progesterone and luteinizing hormone levels during the oestrous cycle in pigs. Biol. of Reprod., 1972, 6, 210 - 218.
Inaba T, Nakazima Y, Matsui N, Imori T: Early pregnancy diagnosis in sow by ultrasonic linear electronic scanning. Theriogenology, 1983, 20, 97-101.

Karlberg $K$ : Factors affecting postweaning oestrus in the sow. Nord. Vet. Med., 1980, 32, 185 - 193.

Karlbom I, Einarsson S, Edqvist LE: Attainment of puberty in female pigs: Clinical appearence and patterns of progesterone, oestradiol-17B and LH. Anim. Reprod. Sci., 1982, 4, 301 - 312.

Kirkwood RN, Lapwood KR, Smith WC, Anderson $I L$ : Plasma concentration of $\mathrm{LH}$, prolactin, oestradiol $17 B$ and progesterone in sows weaned after lactation for 10 and 35 days. J. Reprod. Fert., 1984, 70, 95-102.

Kunavongkrit A, Kindahl H, Madej A: Clinical and endocrinological studies in primiparous zero weaned sows. Zbl. Vet. A., 1983, 30, 616 - 624.

Rodriguez $H$, Kunavongkrit $A$ : Chronical venous catherization for frequent blood sampling in unrestrained pigs. Acta vet. Scand, 1983, 24, $318-320$.

Rojkittikhun T, Einarsson S, Zillinskas $H$, Edqvist LE, Uvnäs-Moberg K, Lundeheim N: Effects of insulin administration at weaning on hormonal patterns and reproductive performance in primiparous sows. J. vet. Med. A., 1993, 40, 161 - 168.

SAS Institute Inc.: SAS Stat User's Guide. Ed 5, Cary, NC, 1985.

Soede NM, Helmond FA, Kemp B: Periovulatory profiles of oestradiol, $\mathrm{LH}$ and progesterone in relation to oestrus and embryo mortality in multiparous sows using transrectal ultrasonography to detect ovulation. J. Reprod. Fert., 1994, 102, 633 - 641.

Soede NM, Kemp B: In synchronized pigs, the duration of ovulation is not affected by insemination and is not a determinant for early embryonic diversity. Theriogenology, 1993, 39, 1043-53.

Soede NM, Noordhuizen JPTM, Kemp B: The duration of ovulation in pigs, studied by transrectal ultrasonography, is not related to early embryonic diversity. Theriogenology, 1992, 38, 653-666.

Soede NM, Van der Lende T, Kemp B, de Koning M: The duration of ovulation in sows using ultrasonography. Congr. on Assisted Reproductive Technology/Andrology, Copenhagen, Denmark, 1991, 128-129.

Stupnicki R, Madej A: Radio immuno assay of LH in blood plasma of farm animals. Endocrinol., 1986, 68, 6-13.

Tilton J, Foxcroft GR, Ziecik AJ, Coombs SL, Williams GL: Time of preovulatory LH surge in the 
gilts and sows relative to the onset of behavioral oestrus. Theriogenology, 1982, 18, 227-236.

Weitze KF, Habeck $O$, Willmen T, Rath D: Detection of ovulation in the sow using transcutaneous sonography. Zuchthyg., 1989, 24, 40 - 42.

Weitze KF, Rabeler J, Willmen T, Waberski D: Interaction between inseminate, uterine and ovarial function in the sow. II. Investigations into the influencing of ovulation by the use of sperm free media. Reprod. Dom. Anim., 1990, 25, 197 - 204.

Weitze KF, Wagner-Rietschel H, Richter L: Standing heat and ovulation in a sow herd. Proc., International Pig Veterinary Society Congress, The Hague, The Netherlands, 1992, p. 460.

Willmen T, Habeck $O$, Wagner-Reitschel H, Richter L, Bortolozzo F, Waberski D, Weitze KF: Experience with sonographic examination of pig ovaries, 12th International congress of Animal Reproduction, the Hague, The Netherlands, 1992, 174-176.

\section{Sammanfattning}

En ultraljuds- och LH-studie av äggstocksaktiviteten hos sugga under brunst

Femton förbrunst- och brunstperioder studerades hos 6 korsningssuggor efter avvänjning (andra till fjärde kull, Svensk Lantras x Svensk Yorkshire). Brunstsymptom kontrollerades och follikeltillväxt samt ovulation följdes med ultraljud via rektum. Via en inopererad kateter togs blodprov för LH- och progesteronanalyser.

Brunstlängden (ståreflexen) var i medeltal $47 \pm 12.4$ tim och intervallet från ståreflexens början till slutet av ovulationen var $39 \pm 12.4$ tim (variation $20-64$ tim). Den maximala LH-koncentrationen var $3.7 \pm$ $0.8 \mu \mathrm{g} / \mathrm{l}$ och intervallet från maximal LH-koncentration till ovulation var $23 \pm 8.4$ tim (variation $8-32$ tim). Ståreflexen började i medeltal 13 tim efter det av den maximala LH-koncentratioen var uppnådd (variation $-4- \pm 36$ tim).

Perifera plasma koncentrationen av progesteron hade ett normalt cykliskt förlopp hos alla suggorna. Låga koncentrationer (medelvärde $1.1-1.3 \mathrm{nmol} / \mathrm{l}$ ) sågs under förbrunst och brunst, höga koncentrationer sågs från dag 10 till dag 16 i brunstcykeln.

Konklusion: Ultraljudsundersökning är en mycket lämplig metod att använda för en noggrann bedömning av ovulationstidpunkten hos suggor. Undersökningarna måste dock göras upprepade gånger.

(Received November 2, 1994; accepted May 22, 1995).

Reprints may be obtained from: A.M. Dalin, Department of Obstetrics and Gynaecology, Swedish University of Agricultural Sciences, P.O. Box 7039, S-750 07 Uppsala, Sweden. 